\title{
ANALISIS DAN PERANCANGAN SISTEM INFORMASI INVENTORY PADA PT. INSAN DATA PERMATA
}

\author{
Agung Cahyo Wijoyo', Dian Hermanto \\ Program Studi Informatika, Fakultas Teknik dan Ilmu Komputer, Universitas Indraprasta PGRI \\ Jalan Raya Tengah No 80, Kelurahan Gedong, Pasar Rebo, Jakarta Timur \\ agungcahyo084@gmail.com ${ }^{1}$, dianh.lectures@gmail.com²
}

\begin{abstract}
Abstrak
Sistem inventory merupakan suatu sistem untuk mengetahui persediaan stok barang pada suatu tempat. Sistem inventory sudah banyak digunakan atau dikembangkan pada suatu tempat dengan berbagai macam teknologi dan sistem. Permasalahan pada PT. Insan Data Pemata ini adalah belum tersedianya sistem inventory barang sehingga belum bisa mengontrol stok barang yang tersedia. Maka peneliti akan membangun sistem informasi suatu sistem inventory yang berbasis desktop, sehingga informasi tentang stok barang akan diketahui secara jelas dan terperinci. Sistem inventory ini akan diterapkan menggunakan sistem informasi berbasis desktop. Program ini dibuat dengan menggunakan perangkat lunak XAMPP, dan NetBeans IDE 8.2 serta database MYSQL, program ini berfungsi untuk mengolah data tentang implementasi sistem informasi inventory pada PT. Insan Data Permata. Dengan adanya sistem informasi inventory pada PT. Insan Data Permata, semua kegiatan yang berhubungan dengan pendaftaran pelanggan, pengolahan barang, pengolahan transaksi pengadaan barang, penjualan barang dan laporan tidak lagi secara manual.
\end{abstract}

Kata Kunci: Sistem Informasi Inventory, Sistem Informasi Penjualan, Java, MySql

\begin{abstract}
Inventory system is a system to know the stock inventory of goods in a place. Inventory system has been widely used or developed in a place with a wide range of technologies and systems. The problem in PT. Insan Data Pemata is the unavailability of inventory goods system that cannot control the stock of goods available. Then the researcher will build the information system of a desktop-based inventory system, so that information about the goods stock will be known clearly and itemized. This inventory system will be implemented using a desktopbased information system. The program is created using XAMPP software, and NetBeans IDE 8.2 as well as a MYSQL database, this program serves to process data about the implementation of inventory information system in PT. Insan Data Permata. With the system of inventory information on PT. Insan Data Permata, all activities related to customer registration, processing goods, processing of goods procurement transactions, sales of goods and reports no longer manually.
\end{abstract}

Keywords: Inventory Information System, Sales Information System, Java, MySql,

\section{PENDAHULUAN}

Saat ini teknologi dan informasi setiap detiknya mengalami perkembangan. Setiap detiknya teknologi dan informasi semakin canggih. Pesatnya kemajuan teknologi membuat persaingan semakin sangat ketat diantara perusahaan-perusahaan diberbagai bidang. Dalam bidang retail peran teknologi dan informasi sangat berpengaruh. Untuk dapat bertahan dibutuhkan suatu sistem yang dapat mengelola dan mengatur data-data dan informasi pembelian dan penjualan barang yang semula menggunakan microsoft excel, mengalami perkembangan dengan digan Dengan adanya hal ini dapat mempermudah dan mempercepat dalam melaksanakan kegiatan pembelian dan penjualan barang. Adanya sistem informasi yang terkomputerisasi data dapat diolah menjadi informasi yang tepat, akurat, sehingga dapat digunakan untuk membantu mengambil keputusan oleh pimpinan dan untuk mengukur apakah sejauh mana tujuan perusahaan telah tercapai.

PT. Insan Data Permata merupakan perusahaan distributor mesin absensi yang sudah berdiri sejak tahun 1999, pada perusahaan ini juga merupakan suatu perusahaan yang bergerak dalam bidang pendistribusian mesin absen dan sudah banyak mendapatkan pelanggan dari beberapa perusahaan khususnya di indonesia. Saat ini PT. Insan Data Permata masih menggunakan microsoft excel untuk 
melakukan pencatatan keluar masuknya barang, sehingga seringkali user kesulitan untuk mencari data-data yang telah lama tersimpan yang pada akhirnya user kehilangan banyak waktu hanya untuk mencari sebuah data. Selain itu data dan informasi yang ada saat ini dirasa kurang akurat. Maka dibutuhkan pemanfaatan teknologi informasi yang nantinya dapat meningkatkan kualitas kerja dan memberi kemudahan mengolah dan memperoleh informasi yang cepat dan akurat. Berdasarkan masalah yang sudah peneliti paparkan, maka dari itu peneliti mempunyai sebuah gagasan untuk membuat sebuah sistem yang nantinya akan sangat bermanfaat bagi PT. Insan Data Permata. Sistem adalah sekelompok unsur yang erat hubungannya satu dengan yang lain yang berfungsi Bersamasama untuk mencapai tujuan tertentu (Sutabri, 2012). Perancangan sistem merupakan tahap selanjutnya setelah analisa sistem, mendapatkan gambaran dengan jelas tentang apa yang dikerjakan pada analisa sistem, maka dilanjutkan dengan memikirkan bagaimana membentuk sistem tersebut. (Hendarti et al., 2008b)

Tujuan penelitian ini adalah untuk merancang sistem inventory pada PT. Insan Data Permata yang nantinya dapat diakses setiap saat dan menyajikan informasi yang cepat, sehingga dapat menyajikan sajian informasi yang terarah

\section{PENELITIAN RELEVAN}

Penelitian yang dilakukan oleh (Veza, 2017) Perancangan Sistem Informasi Inventory Data Barang Pada PT.Andalas Berlian Motor Penelitian ini bertujuan untuk membuat sebuah sistem informasi yang dapat melakukan pengolahan data pembelian dan penjualan barang, merancang sistem informasi yang dapat menghasilkan laporan-laporan secara terperinci serta memudahkan dalam mencari informasi apabila ada pengkoreksian terhadap data tertentu, membandingkan sejauh mana efisiensi dan efektifitas sistem informasi yang dirancang dengan sistem yang sedang berjalan, membantu dan mempermudah dalam pembuatan laporan-laporan yang dibutuhkan. Simpulan yang diperoleh dari penelitian tersebut adalah setiap perusahaan akan berusaha agar setiap produk yang di jual disukai konsumen, strategi yang di lakukan dalam meningkatkan penjualan adalah dengan adanya strategi yang hebat, karyawan yang berdedikasi, sistem informasi yang bangus serta implementasi yang bagus pula. Akan tetapi perusahaan yang sukses pada saat ini adalah memahami dan memuaskan kebutuhan pelanggan dan memperhatikan program pemasaran dalam memasarkan produk yang disajikan.

Penelitian yang dilakukan oleh Siti Chomsatun SSA, Reza Hidayatulloh, Andi Pardede, Yulianita BR Manik dalam jurnal Program study teknik Informatika Politeknink Negri Batam Vol : III Nomor : 3, 5 Mei 2012, dengan judul Aplikasi penjualan handphone. Penelitian ini bertujuan untuk memberi kemudahan kepada penjual dalam melakukan transaksi penjualan handphone dan pengecekan stok handphone bias lebih cepat dan tepat. Hasil dari penelitian ini adalah Aplikasi penjualan handphone yang dapat mempermudah dalam pengolahan data transaksi dan data stock barang.

\section{METODE PENELITIAN}

Dalam penelitian ini dilakukan pendekatan secara analisis kualitatif, melalui analisis kualitatif mengandung makna suatu penggambaran atas data dengan menggunakan pendekatan kualitatif yang bertujuan memahami suatu situasi pada karyawan perusahaan yang meliputi peran, interaksi dan kelompok. Metode pendekatan kualitatif merupakan sebuah proses investigasi.Penelitian juga lebih menekankan pada objektifitas yang diwujudkan dengan menjelaskan penelitian. Data dan informasi yang digunakan dalam penelitian ini diperoleh dari observasi dan wawancara. Informasi tersebut dalam bentuk dokumen dan catatan kegiatan yang diolah menjadi data. Penelitian ini menggunakan metode penelitian kualitatif deskriptif yaitu penelitian yang menggambarkan tentang suatu kegiatan pada perusahaan. Metode kualitatif ini memberikan informasi yang mutakhir sehingga bermanfaat bagi perkembangan perusahaan PT. Insan Data Permata, serta lebih menfokuskan pada studi kasus yang merupakan penelitian yang terinci mengenai suatu objek tertentu selama kurun waktu tertentu dengan cukup mendalam dan menyeluruh. Studi kasus adalah suatu pendekatan yang bertujuan untuk mempertahankan keutuhan dari objek, artinya data yang dikumpulkan dalam rangka studi kasus dipelajari sebagai suatu keseluruhan yang terintegrasi. Dimana tujuannya adalah untuk memperkembangkan pengetahuan yang menekankan mengenai objek yang bersangkutan. 


\section{HASIL DAN PEMBAHASAN}

\section{Analisis Permasalahan}

Setelah di Analisa ada beberapa kelemahan dari sistem informasi yang sedang berjalan, diantaranya:

1. Dalam memasukkan data masih menggunakan cara manual yang belum menggunakan sistem database sehingga pemasukan data menjadi kurang efektif.

2. Penyimpanan data belum terintegrasi dengan baik sehingga pencarian data menjadi tidak efektif.

3. Adanya kesulitan dalam memperbaiki data apabila terdapat perubahan data yang baru

4. Adanya kesulitan didalam pembuatan laporan

\section{Alternatif Penyelesaian Masalah}

Setelah menganalisa dan mengevaluasi sistem yang sedang berjalan, maka sebagai tindak lanjut bagi penyelesaian masalah maka jalan alternatifnya adalah:

1. Merancang suatu sistem yang terkomputerisasi yang dapat menghasilkan informasi yang lebih cepat, tepat, dan akurat

2. Menyimpan data perpustakaan ke dalam bentuk database sehingga mudah dalam pengolahannya

3. Semua data yang di simpan ke dalam database apabila di perlukan dapat di program menggunakan perintah pemrograman java.

4. Cetak laporan dengan memanggil database dengan menggunakan perintah pemrograman java

\section{Aturan Bisnis Sistem yang Diusulkan}

Aturan inventaris dalam sistem inventory yang diusulkan pada PT. INSAN DATA PERMATA sebagai berikut :

1. Pembelian Customer

a. Customer secara langsung mengajukan permintaan barang kepada sales dengan membuat Purchase Order

b. Sales mengirimkan faktur permintaan pengadaan ke bagian purchasing

c. Purchasing akan mengirimkan order confirmation ke pihak customer, order confirmation berisi list barang sesuai permintaan, harga serta ongkir yang akan dibebankan ke pihak customer nantinya

d. Kemudian pihak customer mengembalikan order confirmation sekaligus memberi tanda validasi bahwa pihak customer mengorder sesuai list yang tertera didalam order confirmation

2. Pengadaan Barang

a. Purchasing mengecek keberadaan stock, jika barang ready maka barang tersebut siap dikirim, jika barang tidak available di stock warehouse maka purchasing membuat purchase order ke supplier untuk meminta pengadaan barang.

b. Purchasing memasukan data penjualan sesuai barang yang siap dikirim

3. Pembayaran

a. Customer langsung melakukan pembayaran sesuai dengan barang yang diterima sesuai dengan tagihan yang dikirim

b. Customer menerima bukti pembayaran.

c. Pembayaran bisa dilakukan dengan cara tranfer antar bank atau pun dengan cara langsung atau cash

4. Pengiriman

a. Pengiriman dilakukan oleh pihak crew warehouse secara langsung maupun melalui ekspedisi

b. Bagian crew warehouse akan menerima bukti kirim dan kemudian diserahkan kepada customer.

5. Pelaporan

a. Bagian purchasing akan memberikan laporan tentang purchase order supplier dan stock barang setiap bulannya

b. Bagian finance akan memberikan laporan berupa laporan yang ada

c. Bagian sales akan memberikan laporan berupa laporan penjualan setiap bulannya

Semua laporan akan diperika oleh manager dan akan diteruskan kepada pihak direktur 


\section{Diagram Konteks}

Berikut ini merupakan penggambaran tentang sistem yang yang diusulkan pada Sistem Informasi Inventory Pada PT. INSAN DATA PERMATA secara keseluruhan dalam bentuk diagram konteks.

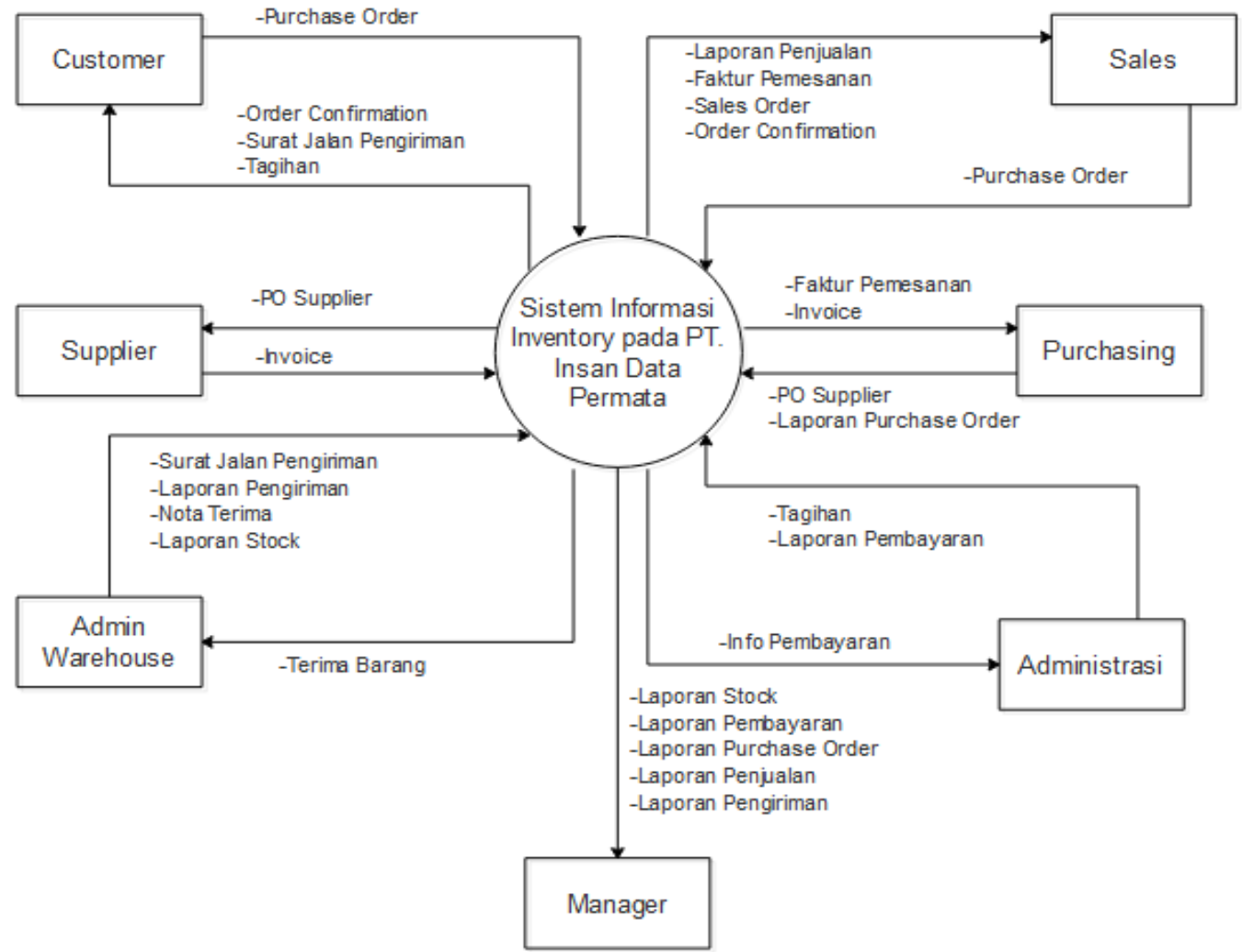

Gambar 1. Diagram Konteks yang Diusulkan

\section{Tampilan Aplikasi}

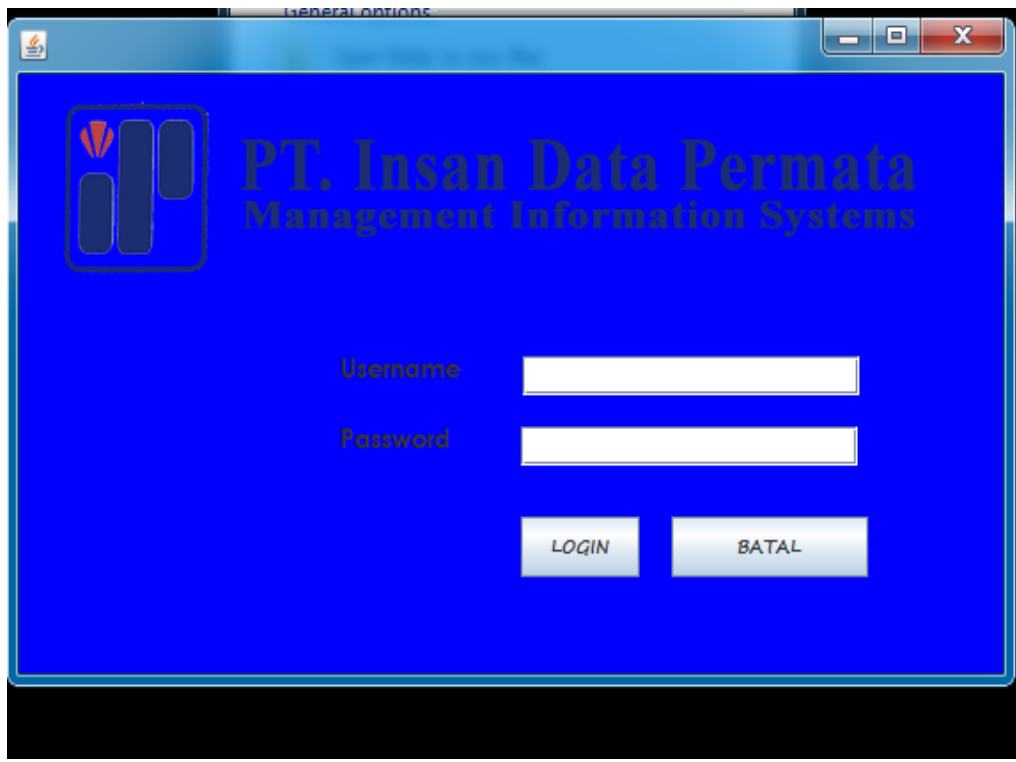

Gambar 1. Tampilan Form Login

Gambar diatas merupakan Form login yang digunakan untuk melakukan akses ke menu utama 


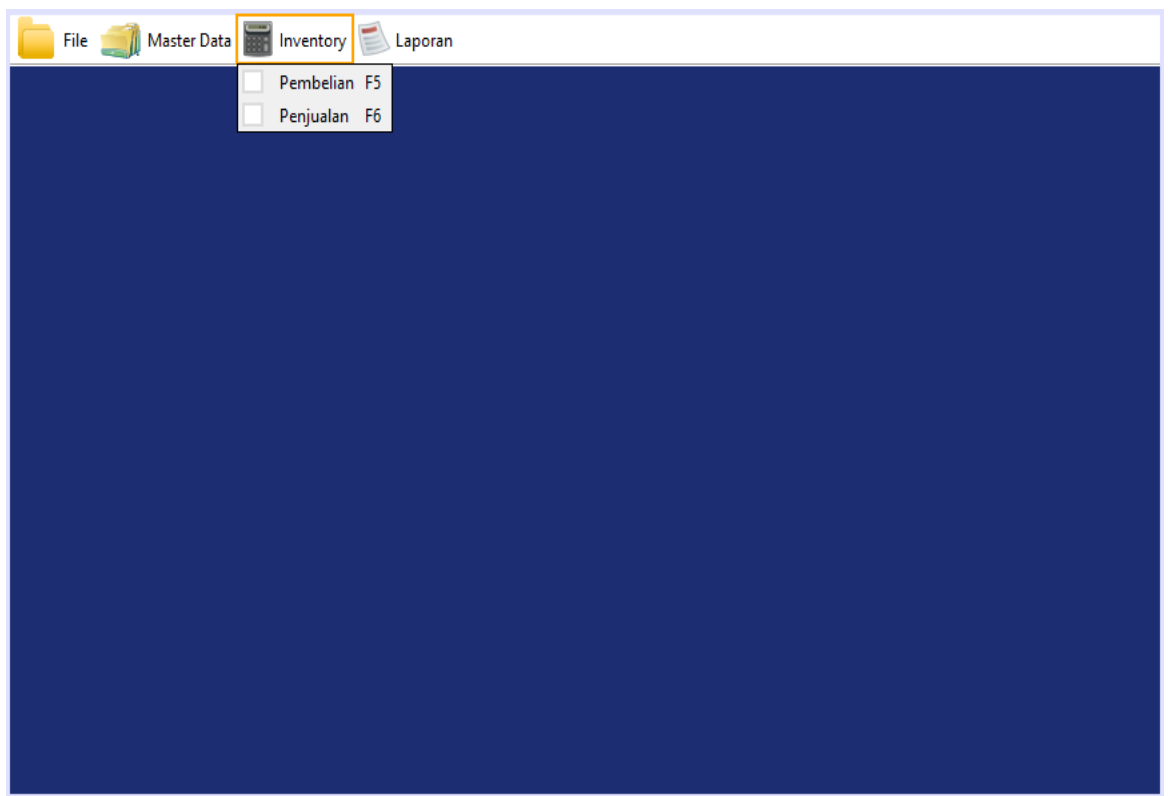

Gambar 2. Tampilan Menu Utama

Gambar diatas merupakan Menu Utama. Setelah berhasil login akan masuk ke menu utama, dalam menu utama terdapat beberapa menu diantaranya Menu File, Menu Master Data, Menu Inventory dan Menu Laporan

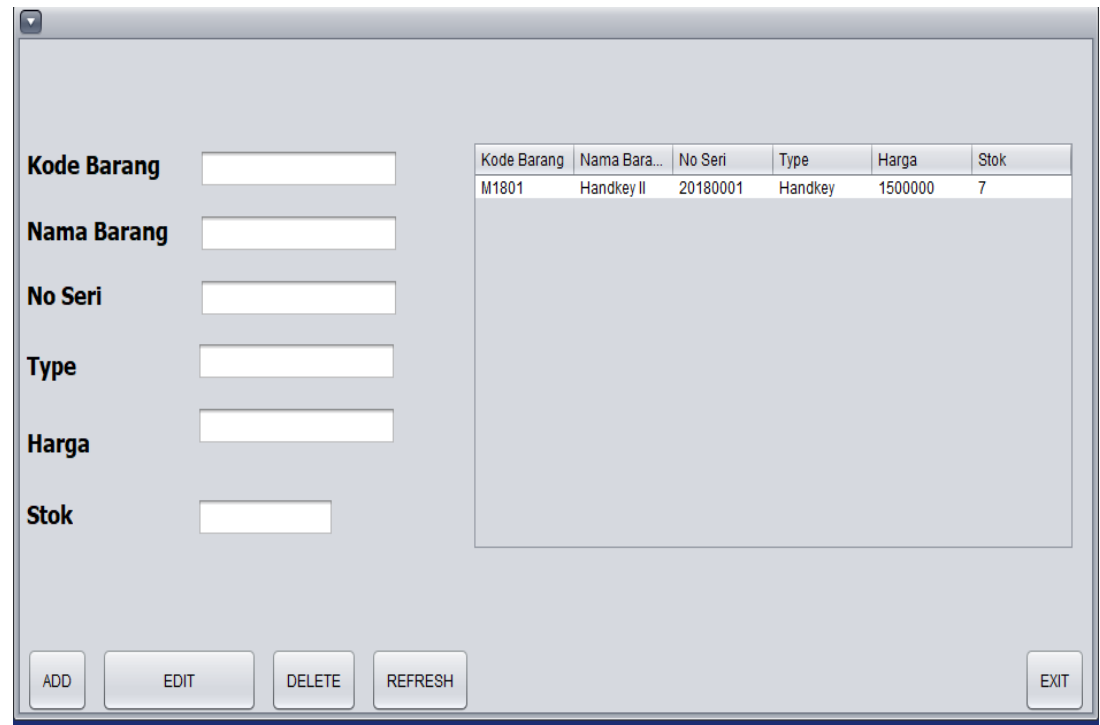

Gambar 3. Tampilan Form Data Barang

Gambar diatas merupakan form data barang. Forn data barang dapat diakses dengan memilih menu master yang di dalamnya terdapat menu data barang jika di klik menu data barang maka akan muncul bentuk form data barang untuk melakukan penginputan data barang pada PT. Insan Data Permata secara keseluruhan 
Management Information Systems

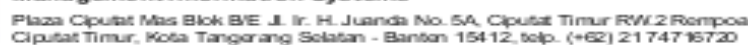

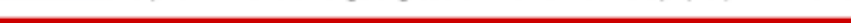

\begin{tabular}{llllll}
\hline \multicolumn{5}{c}{ LAPORAN DATA BARANG } \\
Kods Barang & Nama Barang & No Serial & Type & Harge & Qty \\
20191202 & FacelD & 123456 & Face & 10000000 & 24 \\
20191201 & Handloy II & 1234 & Handbey & 15000000 & 10
\end{tabular}

Gambar 1. Tampilan Laporan Data Barang

Gambar diatas merupakan tampilan laporan data barang

\section{SIMPULAN}

Dengan dibuatnya Analisis dan Perancangan Sistem Informasi Inventory pada PT. Insan Data Permata. semua kegiatan yang berhubungan dengan pendaftaran pelanggan, pengolahan barang, pengolahan transaksi pengadaan barang, penjualan barang dan laporan tidak lagi secara manual. Dengan adanya jasa komputer sebagai alat bantu, peneliti memiliki kesimpulan dengan menggunakan sistem ini dapat memberikan beberapa keuntungan sebagai berikut Dengan menggunakan aplikasi yang dibuat ini dapat memudahkan pegawai di PT Insan Data Permata dalam mencatat dan mendataan barang dan transaksi penjualan barang. Pengolahan data PT Insan Data Permata lebih efektif, serta keamanan terhadap data lebih terjamin, Proses dalam pembuatan laporan dapat dilakukan dengan cepat dan akurat serta efisien, Memudahkan pegawai untuk memantau atau mengontrol data yang ada dalam database

\section{DAFTAR PUSTAKA}

Hendarti, H., Anton, A., Didi, D., \& Cakra, M. (2008b). Analisis dan Perancangan Sistem Informasi Akuntansi Penjualan dan Persediaan. The Winners, 9(1), 88. https://doi.org/10.21512/tw.v9i1.733

Levin, R. (2004). Inventory management. Journal of the American Dental Association. https://doi.org/10.14219/jada.archive.2004.0278

Sudarsono, N., \& Sukardi. (2015). Sistem Informasi Inventory Berbasis Web di PT Autotech Indonesia. Eksplora Informatika.

Sutabri, T. (2012). Analisis Sistem Informasi.Andi Yogyakarta

Veza, O. (2017). PERANCANGAN SISTEM INFORMASI INVENTORY DATA BARANG PADA PT.ANDALAS BERLIAN MOTORS (Studi Kasus : PT Andalas Berlian Motors Bukit Tinggi). Jurnal Teknik Ibnu Sina (JT-IBSI). https://doi.org/10.36352/jt-ibsi.v2i2.63 